\title{
The function of regressions in reading: Backward eye movements allow rereading
}

\author{
Robert W. Booth • Ulrich W. Weger
}

Published online: 11 August 2012

(C) Psychonomic Society, Inc. 2012

\begin{abstract}
Standard text reading involves frequent eye movements that go against normal reading order. The function of these "regressions" is still largely unknown. The most obvious explanation is that regressions allow for the rereading of previously fixated words. Alternatively, physically returning the eyes to a word's location could cue the reader's memory for that word, effectively aiding the comprehension process via location priming (the "deictic pointer hypothesis"). In Experiment 1, regression frequency was reduced when readers knew that information was no longer available for rereading. In Experiment 2, readers listened to auditorily presented text while moving their eyes across visual placeholders on the screen. Here, rereading was impossible, but deictic pointers remained available, yet the readers did not make targeted regressions in this experiment. In Experiment 3, target words in normal sentences were changed after reading. Where the eyes later regressed to these words, participants generally remained unaware of the change, and their answers to comprehension questions indicated that the new meaning of the changed word was what determined their sentence representations. These results suggest that readers use regressions to reread words and not to cue their memory for previously read words.
\end{abstract}

Keywords Eye movements $\cdot$ Regressions $\cdot$ Reading · Deictic pointers

\footnotetext{
R. W. Booth $(\square)$

Department of Psychology, Ișık University,

Psikoloji Bölümü,

Şile 34980, İstanbul, Turkey

e-mail: rob.booth.psych@gmail.com

U. W. Weger

University of Kent,

Canterbury, UK

Over the past 30 years, numerous studies have illuminated the characteristics of eye movements, and the mechanisms that direct the eyes toward novel information: In reading, this equates to directing the eyes toward upcoming words in the visual periphery (for overviews, see Rayner, 1998, 2009). Much less is known about regressions - that is, eye movements in the direction opposite to normal reading. Regressions make up $15 \%-25 \%$ of eye movements during normal reading (e.g., Rayner \& Pollatsek, 1989): Most are fixations of the word immediately to the left of the lastfixated word (Vitu \& McConkie, 2000), but a minority are longer-range regressions to an earlier word or to an earlier segment of the text. Regressions are planned and executed differently from forward-directed saccades (cf. McConkie, Kerr, Reddix, \& Zola, 1988; Vitu \& McConkie, 2000), and their nature and function is not well understood. Although they go against the normal order of word processing, they do not impede comprehension (Kolers, 1968).

In this article, we will test two accounts of the function of longer-range regressions (i.e., of more than one word; shorter-range regressions may serve different functions; Vitu, 2005). The first, and dominant, account argues that readers make regressions to reread words that they have already fixated or skipped. The second, more recent account holds that regressions serve to cue readers' memory for words that they have already read. According to this account, actual rereading would be merely an incidental byproduct of a regression. We expound on both accounts below.

The most obvious explanation of these longer-range regressions (see Rayner, 1998) is that they allow the reader to reread information that they have missed, forgotten, or are unsure about (hereafter, the "rereading hypothesis"). This hypothesis seems consistent with the evidence: Readers make more regressions when the text is complex (Rayner \& Pollatsek, 1989), when the topic changes (Hyönä, 1995), when the text contains grammatical errors or ambiguities 
(Inhoff, Greenberg, Solomon, \& Wang, 2009), or when they encounter information that disambiguates the preceding text (Blanchard \& Iran-Nejad, 1987; Frazier \& Rayner, 1982). All of these effects suggest that readers make regressions to reread or check previously read words.

Another way to account for regressions is to assume that they help the reader reinstate a cognitive action that is associated with a cognitive process that originally occurred at the regressed-to location (Kennedy, 1992); in other words, they serve to cue the reader's memory for what has previously been read (hereafter, the "deictic pointer hypothesis"; see Ballard, Hayhoe, Pook, \& Rao, 1997; Spivey, Richardson, \& Fitneva, 2004). Readers often have a surprisingly good memory for the position of information on the page: Kennedy and Murray (1987) found that readers could make accurate regressions 60 character spaces in length. Reading a long text imposes considerable demands on working memory; it is plausible that readers could use words' positions on the page as a kind of "external memory" (see O'Regan, 1992). By returning to a location on the page, some of the properties of the text might be activated (namely, their spatial properties), making it easier to retrieve information associated with that location (Ferreira, Apel, \& Henderson, 2008). Therefore, the deictic pointer hypothesis leads to the premise that moving the eyes back to the location of a previously read word is sufficient to cue the reader's memory for that word, rendering actual rereading unnecessary.

It was Hebb (1968) who originally proposed that eye movements are important in memory, specifically in visual working memory (WM) and imagery. Eye movements follow similar patterns when viewing a stimulus and when later inspecting that same stimulus using imagery (Borst \& Kosslyn, 2008; Brandt \& Stark, 1997). Participants fixate the empty space where referred-to objects have previously been seen (Altmann, 2004; Altmann \& Kamide, 2009; Ferreira et al., 2008) and while trying to recall stimuli that had previously occupied that location (Richardson \& Spivey, 2000; Spivey \& Geng, 2001; Theeuwes, unpublished data, as cited in Theeuwes, Belopolsky, \& Olivers, 2009). However, from these studies it remains unclear whether the eye movements are functional or simply a by-product of retrieving a visual memory (see Altmann, 2004; Ferreira et al., 2008, for similar arguments).

More direct evidence that eye movements aid memory retrieval has come from studies in which retrieval was impaired by eye movements away from the location of the to-be-remembered item. Hale, Myerson, Rhee, Weiss, and Abrams (1996) asked participants to remember the locations of objects: When participants had to make a lateral eye movement following the presentation of each object, their spatial memory performance was impaired. Similarly, Lawrence, Myerson, Oonk, and Abrams (2001) found that saccades to a flashing peripheral cue disrupted spatial WM; importantly, unfixated cues did not disrupt WM, suggesting that this effect is truly related to eye movements and not an artifact of distraction. This conclusion was supported by Lawrence, Myerson, and Abrams (2004), who found that a spatial shift of attention did not disrupt WM as much as a physical eye movement. Similarly, Postle, Idzikowski, Della Salla, Logie, and Baddeley (2006, Exp. 4) found that visual WM was specifically vulnerable to disruption by eye movements, but not by other secondary tasks.

Perhaps the strongest evidence for the importance of eye movements in memory has come from Laeng and Teodorescu (2002, Exp. 2), who asked participants to view a grid containing images of tropical fish. The participants either had to maintain a central fixation or could move their eyes freely. The images were then removed, and the participants were asked about the physical characteristics of the fish. Participants who could move their eyes during viewing were more likely to move their eyes during recall, whereas those who fixated centrally during viewing tended also to fixate centrally during recall. Most importantly, participants who could move their eyes during viewing but were restricted to a central fixation during recall remembered significantly fewer details about the fish than did the other groups (although see Spivey \& Geng, 2001). This suggests that making similar eye movements during viewing and recall has a functional role in memory recall, and that eye movements are not just byproducts of retrieving visual memories (Mast \& Kosslyn, 2002).

The evidence therefore suggests that eye movements may be capable of cuing recall. Reading seems an ideal task on which to use this ability, as it requires the encoding of large amounts of information that is bound to a series of specific spatial locations on the page. The deictic pointer account of regressions is therefore plausible, and given the uncertainty surrounding the function of regressions, it deserves careful consideration. Many of the characteristics of regressions (e.g., that they occur when readers are unsure about the meaning of the sentence or when the text's topic changes) can equally well be explained by the deictic pointer hypothesis as they can by the rereading hypothesis.

The rereading and deictic pointer hypotheses are not mutually exclusive: Regressions may benefit reading by allowing rereading as well as by cuing memory. It is important to investigate whether deictic pointers are indeed used during reading and, if so, their importance in programming regressions. This question was explored by Inhoff and Weger (2005, Exp. 3), who showed participants a factdefining statement sentence, followed by a question sentence, which asked the participant about some precise detail from the statement sentence. On half of the trials, the statement sentence was removed when participants fixated the question sentence (this is a variation of the gaze-contingent 
boundary paradigm; see Rayner, 1975). This prevented rereading but arguably still allowed participants to cue their memory for the sentence by making a regression. When the sentence disappeared, participants made a regression on only $4 \%$ of trials, as opposed to $43 \%$ when the sentence remained visible. The fact that readers made many fewer regressions when the sentence could not be reread provides initial evidence that rereading is the major purpose of regressions. Although this task was unlike normal reading and the regressions that were elicited may be functionally different from those in normal reading, this was an advantage for testing the deictic pointer hypothesis, since the task encouraged regressions, and using deictic pointers would provide a performance advantage. The fact that readers did not use deictic pointers in this situation suggests that they do not use them in normal reading. The present research aimed to further explore this result.

\section{Experiment 1}

Inhoff and Weger's (2005) experiment supports the rereading hypothesis, but it has a methodological limitation: The statement sentence disappeared completely before the participant answered the comprehension question, which made rereading impossible. However, deictic pointers-which presumably relate to the positions of the words - may also have disappeared. The deictic pointer hypothesis includes the assumption that readers can more easily recall a previously read word if they fixate its location, but if the sentence disappears completely, it may be more difficult to do this, since spatial cues — such as adjacent words - are not available (although see Altmann, 2004; Altmann \& Kamide, 2009). Thus, participants may not have regressed because they knew that they could not use deictic pointers to retrieve the answer, not because they knew that they could not reread the answer. Therefore, Inhoff and Weger's results can also be accommodated by the deictic pointer hypothesis.

Our Experiment 1 eliminated this problem by changing the letters in the statement sentences, rather than removing them. For example, participants were presented with the statement sentence "My mother came from England and my father from Hungary"; after they read this statement, it was replaced with "Gi sowmty gorm hore Yngrwio ptg de ugewse huim Muvfrew." This made rereading the statement impossible. However, the now-illegible statement preserved deictic pointers, because each word's position, length, and capitalization were still available; if participants wanted to fixate a word from the statement, they could easily do so, they just could not actually read it. The deictic pointer hypothesis therefore yields the predictions that participants should have regressed when the statement was illegible and that regressing should improve their accuracy on the comprehension questions. However, the rereading hypothesis yields the prediction that when the statement sentence was illegible, participants should have realized that they could not reread the statement and therefore made no regressions; likewise, any regressions that they did make should not have improved their accuracy on the comprehension questions. Importantly, legibility was blocked, so participants were always aware whether the statement would be legible.

The present research also extends the work of Inhoff and Weger (2005) by manipulating visuospatial WM load: Participants remembered the locations of letters during the reading task. If readers regressed to cue their memory for words' semantic content, visuospatial WM was presumably necessary for retaining these words' locations. Also, eye movements have been selectively linked to spatial WM in the literature (Lawrence et al., 2001; Lawrence et al., 2004; Postle et al., 2006). Therefore, the deictic pointer hypothesis predicts that loading visuospatial WM with a secondary task should disrupt reading and comprehension performance in several ways. Firstly, it should be more difficult to retain the locations of words, and so regressions should be less accurate. Deictic pointers might also be less likely to be formed or be more fragile. Finally, more regressions may be made under high load, to alleviate the additional WM load from retaining the locations of words.

On the other hand, the rereading hypothesis yields the prediction that visuospatial WM load should not affect regression frequency or comprehension accuracy. Although high load might make it harder to accurately regress to the target word, there was no time limit: Participants would eventually find and reread the target word. When the statement sentence was illegible, rereading could not aid comprehension accuracy, regardless of load; therefore, no effect of visuospatial WM load on comprehension accuracy would be predicted, regardless of legibility. Note that visuospatial WM load should not greatly affect comprehension during initial reading of the statement sentence, since normal reading utilizes phonological more than visuospatial WM (e.g., Calvo \& Eysenck, 1996).

These two changes ensured a more thorough test of the rereading and deictic pointer hypotheses.

\section{Method}

Participants A group of 22 undergraduates from the University of Kent participated for course credit. All were native English speakers with no vision or reading problems.

Design The experiment employed a $2 \times 2 \times 2$ repeated measures design. The factors were Statement Legibility (legible or illegible), Target word's Position in the sentence (early or late), and WM Load (high [five items] or low [two items]). 
Apparatus and stimuli The experiment was conducted using SR Research's Experiment Builder and an EyeLink 1000 eyetracker. Participants sat supported by a chin- and headrest $68 \mathrm{~cm}$ from a 19-in. ViewSonic G90fB monitor.

The sentences were taken from Inhoff and Weger (2005; see Appx. A below). There were 40 statement sentences, each from five to ten words long, and containing two potential target nouns. Each statement sentence was followed by one of two question sentences. For example, the statement "My mother is younger than my father" was followed by either "Who was born earlier?" in which case father became the target, or "Who was born later?" in which case mother became the target.

Each statement had a legible version, described above, and an illegible version. This was made by substituting every letter in the sentence. Spaces, punctuation, and capitalization were preserved so as to allow accurate regressions within the illegible sentences. The illegible sentences were identical for all participants and did not contain any real words or pronounceable nonwords.

Text was presented in 12-point Courier font. The letters subtended approximately $0.25^{\circ}$. The question sentence directly followed the statement sentence, on a single line.

For the WM task, 20 high- and 20 low-load study phase stimuli were prepared. Each stimulus consisted of Xs, spread irregularly on a single line (see Fig. 1). In the highload condition, there were five Xs; in the low-load condition, there were two. Stimuli were also prepared for the recognition test phase; these were either identical to their respective study phase stimulus, or identical except that one $\mathrm{X}$ had been moved slightly to one side. There were equal numbers of identical and nonidentical stimuli.

Procedure The participants were tested individually. After a briefing, the eyetracker was calibrated using three fixations: Gaze was only measured in the horizontal dimension. Calibration was validated using another three fixations and was repeated if any fixation was inaccurate by more than $0.5^{\circ}$. A drift correction was performed before each trial; if this was inaccurate by more than $0.5^{\circ}$, the tracker was recalibrated.

Each trial began with the WM study phase stimulus, which was presented for $2 \mathrm{~s}$ (see Fig. 1); participants had to remember the positions of the Xs. This was followed by the statement and question sentences, which were presented as a single line of text, for $5 \mathrm{~s}$. Gaze position was recorded during this time. The participant gave a verbal answer to the question sentence; this was recorded by the experimenter, who sat out of sight. Participants were told to concentrate on accuracy, as the speed of response was unimportant. In the illegible condition, the computer switched the legible statement for its illegible version when the participant's gaze crossed an invisible boundary between the statement and question sentences. This could happen at any time, and did not affect the timing of the trial.
Next, the WM test phase stimulus was presented for $5 \mathrm{~s}$, or until the participant made a response. Each participant pressed the " $R$ " key if the test stimulus was identical to the study phase stimulus, and " $\mathrm{W}$ " if it was not.

There were two blocks of 20 trials, one for the illegible condition, and one for the legible condition. Block order was counterbalanced. Sentences were randomly allocated to the conditions of the Target Position and WM Load factors and were presented in a random order.

Dependent variables The dependent variables were the accuracy on the comprehension task; the proportion of trials on which regressions were made, where a regression was defined as a saccade from the question sentence back to the statement sentence; regression depth, or the distance in character spaces from the end of the statement sentence to the landing position of the regression (this was not the overall length of the regression, but a measure of how deeply it penetrated back into the statement sentence); and regression error, which was the distance in character spaces between the regression's landing position and the center of the target word. These measures were calculated for the first and the second regressive fixation for each trial, as readers would often require two saccades to fixate the target of a regression (Inhoff \& Weger, 2005). Fixations preceded and/ or followed by a blink were excluded when calculating the dependent variables.

\section{Results and discussion}

The participants took $M=3,530 \mathrm{~ms}(S D=1,136)$ to read the statement sentence, fixating for $M=257.83 \mathrm{~ms}$ ( $S D=$ 153.83) and making saccades of $M=10.90$ letter spaces $(S D=11.27)$. Participants fixated the target word for $M=$ $625.41 \mathrm{~ms}(S D=444.14)$ before fixating the question, and fixated the target for $M=260.62 \mathrm{~ms}(S D=175.42)$ on the first pass through the sentence; the target word was skipped on $23.64 \%$ of the trials. None of these values were affected by Legibility $(t \mathrm{~s}<1.5, p \mathrm{~s}>.14)$. While initially reading the statement sentence, participants made $M=4.58(S D=2.11)$ regressions in the legible condition and $M=4.08$ ( $S D=$ $1.93)$ in the illegible condition, $t(861)=3.56, p<.001$. However, Legibility did not affect the number of regressions that they made to the target word, $M=0.93(S D=1.12)$, $t(861)=1.25, p=.21$.

Regressions from the question back to the statement sentence were launched from $M=11.49(S D=7.95)$ letter spaces into the question text, for the illegible condition, and from $M=13.18(S D=7.80)$ letter spaces in, for the legible condition. The WM Load manipulation was successful: Participants were significantly more accurate in the low-load condition $(M=.65, S D=.48)$ than they were in the high-load condition $(M=.57, S D=.50), t(816)=2.32, p<.05$. 
Trial sequence for Experiment 1.

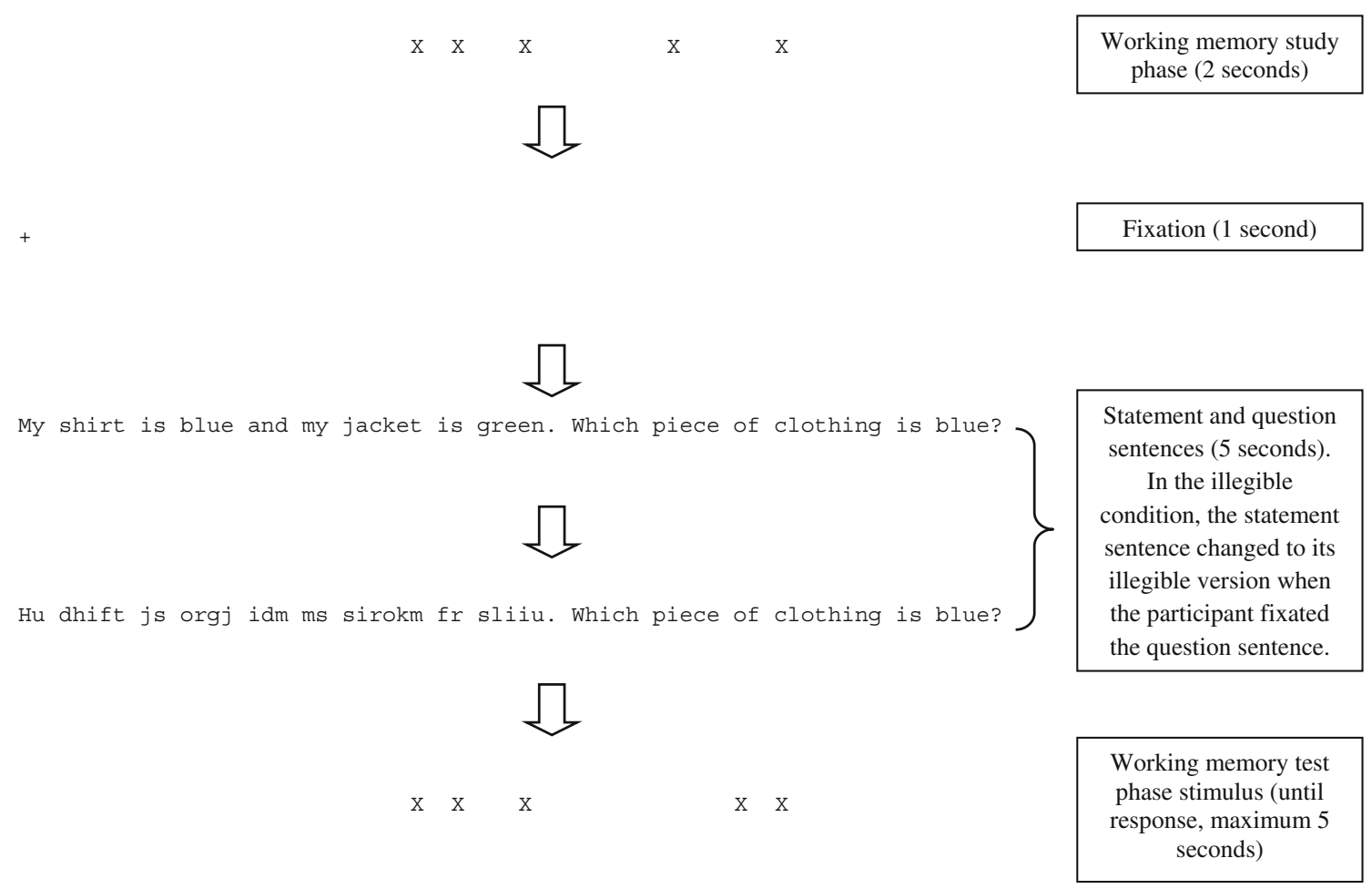

Fig. 1 Trial sequence for Experiment 1

Linear mixed models The number of regressions varied significantly between participants, $F(21,858)=5.31, M S E=$ $0.07, \eta^{2}=.12, p<.001$. To control this noise, and because cell $n$ s were very uneven, we analyzed the data with mixed models, treating individual trials as cases (see Janssen, 2012; Richter, 2006). We tested each dependent variable with the model

$$
\begin{aligned}
\text { Dependent Variable } & =\beta_{0}+u_{0}+\beta_{1} \cdot \text { Statement Legibility } \\
& +\beta_{2} \cdot \text { Target Position }+\beta_{3} \cdot \mathrm{WM} \text { Load } \\
& +\beta_{4} \cdot(\text { Statement Legibility } \times \text { Target Position }) \\
& +\beta_{5} \cdot(\text { Statement Legibility } \times \text { WMLoad }) \\
& +\beta_{6} \cdot(\text { Target Position } \times \text { WMLoad }) \\
& +\beta_{7} \cdot(\text { Statement Legibility } \times \text { Target Position } \\
& \times \mathrm{WM})+ \text { Error }
\end{aligned}
$$

where $\beta_{0}$ is the intercept and $u_{0}$ is the random effect of participants upon the intercept. Restricted maximum likelihood estimation was used. Including the effects of interest yielded a significantly better fit than the null model (all likelihood ratios $>29, p s<.001$ ) for all dependent variables except comprehension accuracy (likelihood ratio $=-15.6, p<.05$ ); for simplicity's sake, all dependent variables were analyzed in the same way. The participants effect was at least marginal for all dependent variables (all $\mathrm{Zs}>1.3, p \mathrm{~s}<.10$ ). Standard ANOVAs with trials as cases yielded near-identical results. Descriptive statistics are presented in Tables 1.

Participants were significantly less likely to make regressions in the illegible than in the legible condition, $F(1,851)=$ $65.34, p<.001$. No other effects were significant on the proportion of trials with regressions (all $F \mathrm{~s}<1.7, p \mathrm{~s}>.19$ ). This suggests that participants usually made regressions when they knew that the statement information was available to reread and supports the rereading hypothesis. The fact that participants did not make more regressions under high WM load refutes the prediction that using deictic pointers reduces the load on WM, and thus contradicts the deictic pointer hypothesis.

Regression depth was affected by a Statement Legibility $\times$ Target Position interaction, $F(1,658)=4.64, p<.05$, so that participants made deeper regressions to early target words when the statement was legible. In other words, participants were less likely to make deep, targeted regressions in the illegible condition. This supports the conclusion that regressions were motivated by the desire to reread information. There was also a Statement Legibility $\times \mathrm{WM}$ Load interaction, $F(1,665)=7.23, p<.01$, so that legibility had a larger effect in the low-load condition. This effect 


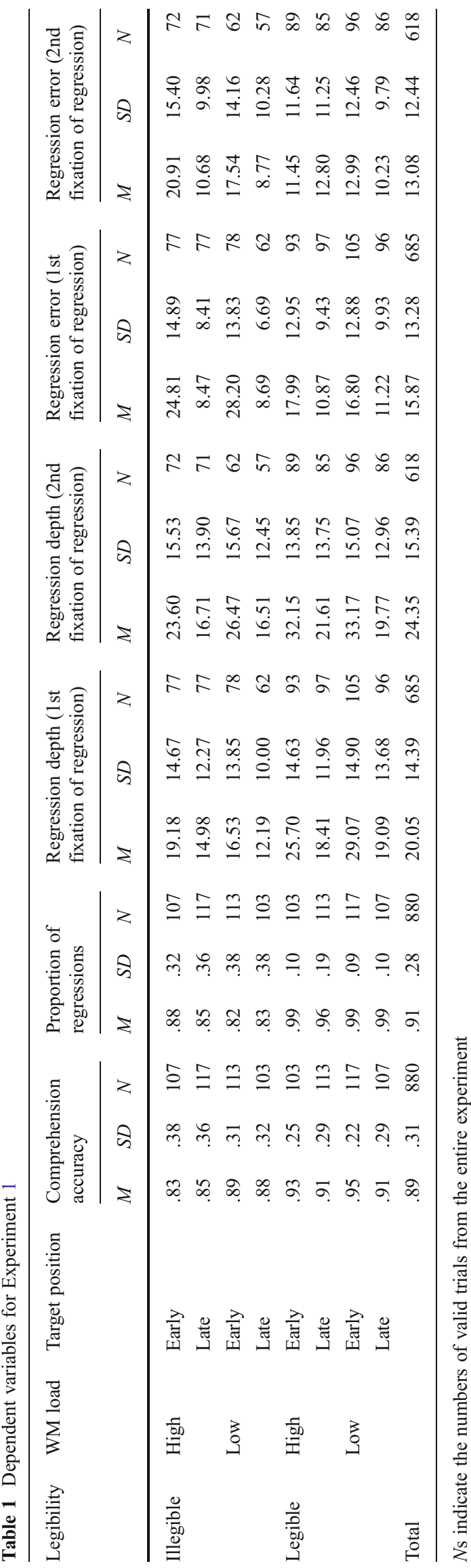

cannot be predicted from either hypothesis and may simply indicate that, when WM load was high, participants were more likely to forget that the statement was unavailable, or to regress out of habit. There were also main effects of statement legibility, $F(1,659)=58.48, p<.001$, and target position, $F(1,658)=44.05, p<.001$. No other effects were significant (all $F_{\mathrm{s}}<0.4, p \mathrm{~s}>.5$ ). For the second fixation of the regression, the main effects of statement legibility, $F(1,597)=$ $28.24, p<.001$, and target position, $F(1,592)=84.79$, $p<.001$, remained, but there were no other significant effects (all $F \mathrm{~s}<2.1, p \mathrm{~s}>.1$ ).

We found a Statement Legibility $\times$ Target Position interaction on regression errors, $F(1,662)=43.21, p<.001$ : Regressions were less accurate to early than to late targets, but this effect was more pronounced in the illegible condition. This is consistent with the idea that regressions had no benefit in the illegible condition, so participants had no reason to make deep, targeted regressions. There were also main effects of target position, $F(1,661)=186.17, p<.001$, and statement legibility, $F(1,663)=14.98, p<.001$. No other effects were significant (all $F \mathrm{~s}<1.6, p \mathrm{~s}>.2$ ). The results were very similar for the second fixation of the regression.

WM load did not affect accuracy on the comprehension task, $F(1,778)=1.50, p=.22$, and did not interact with statement legibility, whether a regression was made, or their combination (all $F_{\mathrm{s}}<1.2, p \mathrm{~s}>.28$ ). Deictic pointers would presumably require visuospatial WM, so these null results suggest that participants were not using deictic pointers in this task. However, these null effects are predicted from the rereading hypothesis. Although null results are not usually interpretable, our interpretation here is supported by other, significant effects in this experiment.

Correlations among dependent variables Importantly, there was a negative correlation between comprehension task accuracy and regression error, but only for the legible condition, $r(389)=-.13, p<.01$, and not the illegible condition, $r(292)=.01, p=.81$. When participants made a regression, they were more likely to subsequently give the correct answer when the regression landed close to its target; however, regressions could not improve comprehension task performance when the statement could not be reread. The second fixation of the regression showed the same relationships. These findings support the rereading hypothesis over the deictic pointer hypothesis.

Comprehension accuracy was higher when participants did not make a regression, $\Phi(778)=-.09, p<.01$. In the illegible condition, regression depth correlated negatively with comprehension accuracy, $r(292)=-.20, p<.001$. Both results suggest that participants made regressions when they were unsure of the correct answer; the latter suggests that targeted regressions were not helpful if the statement 
sentence could not be reread. These results therefore also support the rereading hypothesis. Regression depth and comprehension accuracy did not correlate in the legible condition, $r(389)=.07, p=.14$, because in this condition participants could make targeted regressions, did so more frequently and accurately, and targeted regressions could assist them in giving the correct answer (see Table 1).

Experiment 1 supported the rereading hypothesis more than the deictic pointer hypothesis. Participants made fewer regressions, made shallower and less accurate regressions, and made more comprehension task errors when the statement information was illegible; WM load did not affect comprehension task accuracy. This suggests that readers make regressions to reread information. However, the deictic pointer hypothesis also received some support, in that participants made a large number of regressions in the illegible condition - despite legibility being blocked, so participants knew that they could not reread the target wordand these were somewhat targeted: Regressions were aimed deeper into the statement sentence when the target word appeared earlier in that sentence. This may indicate that regressions both allow rereading and activate deictic pointers. However, it is also possible that participants made regressions in the illegible condition out of habit, or because they forgot that the statement information was illegible (although this is unlikely). A further possibility is that the "regressions" recorded in the illegible condition often reflected a simple recentering of the gaze: The question sentences ended toward the right edge of the screen, and we might not expect participants to hold their gaze to the right at this point. Participants were also answering a question, so the "regressions" may have reflected a kind of gaze aversion (e.g., Doherty-Sneddon \& Phelps, 2005). This recentering account fits with the interactions between legibility and target position on regression depth and on regression error: Untargeted recentering fixations would land farther from early targets, which were nearer the left edge of the screen, than from late targets.

Experiment 2 sought to distinguish whether regressions made when the statement sentence was unavailable reflected accessing of deictic pointers or were simply artifacts of habit, forgetting the statement was unavailable, or recentering the gaze.

\section{Experiment 2}

In Experiment 2, we employed a "simulated" reading task, in which the statement sentence was never presented onscreen. Instead, nonlinguistic markers were used as visuospatial reference points for each word in the statement sentence. Rereading of target words was impossible for the entire experiment, minimizing the chance of participants forgetting that the statement was unavailable. However, deictic pointers were available. Therefore, if participants made regressions in Experiment 2-and if these regressions aided their comprehension performance - this would suggest that participants were using deictic pointers.

\section{Method}

Participants A group of 32 students from the University of Kent (26 female, 6 male) from 18 to 48 years of age $(M=$ $20, S D=5.49$ ) participated for course credit. All were native English speakers with no vision, hearing, or reading problems.

Design For the experiment we employed a $2 \times 2$ repeated measures design. The factors were Target Position (early or late) and WM Load (high [five items] or low [two items]).

Apparatus and stimuli The apparatus and the statement and question stimuli were the same as those used in Experiment 1. To avoid confusion with the simulated words (see below), the WM stimuli were changed from Xs to Os; the WM stimuli were otherwise identical to those used in Experiment 1.

Audio recordings were made of every word from the statement stimuli. Each recording was $600 \mathrm{~ms}$ long and consisted of a single word spoken in a uniform, male voice.

Procedure As in Experiment 1, participants carried out a WM task and a sentence comprehension task simultaneously. Each trial began with the WM study phase, followed by a fixation cross, presented on the left-hand side of the screen for $1 \mathrm{~s}$. Next, the statement was presented by playing the appropriate single-word recordings, each immediately following the last. At each recording's onset, the simulated word "XXXX" appeared on the screen, so that as the auditory statement was presented, a corresponding simulated statement gradually appeared onscreen, with the same word length as the real statement. Participants were instructed to follow this simulated statement with their eyes and to imagine that they were really reading the statement from the screen. Once the statement had been presented, the question text appeared on the same line as the simulated statement, which remained visible. Participants answered the question aloud. Participants were then presented with the WM test phase and responded with a keypress.

Forty trials were presented, with ten randomly allocated to each of the four cells of the design. Five additional, practice trials were presented before the real experiment began; there was no break or signal between the practice and experimental trials.

Dependent variables As before, these were comprehension task accuracy, the proportion of regressions made, 
regression depth, and regression error. Fixations preceded or followed by a blink were excluded from the analysis.

Results and discussion

Reading times, fixation times, and saccade lengths were dictated by the task. Nonetheless, participants fixated the target simulated word for $M=615.25 \mathrm{~ms}(S D=370.51)$; the target simulated word was skipped on $31 \%$ of trials. These figures are comparable to those from Experiment 1 and suggest, firstly, that participants were following the instructions correctly and, secondly, that they had ample opportunity to form deictic pointers. Due to a programming error, WM accuracy was not recorded. Regression launch sites were $M=9.52(S D=11.20)$ letter spaces from the beginning of the question sentence.

Linear mixed models Regression behavior was influenced by individual differences: Some participants made many regressions, whereas others made few or none. To control this noise, we analyzed each dependent variable using the model

Dependent Variable $=\beta_{0}+u_{0}+\beta_{1} \cdot$ Target Position

$$
\begin{aligned}
& +\beta_{2} \cdot \text { WM Load } \\
& +\beta_{3} \cdot(\text { Target Position } \times \text { WM Load })+\text { Error, }
\end{aligned}
$$

where $\beta_{0}$ and $u_{0}$ denote the intercept and the random effect of participants on the intercept, as before. For regression errors and regression depth, including the effects of interest yielded significantly better fit than the null model for both the first and second fixations of the regression (all likelihood ratios $>22.7, p \mathrm{~s}<.001$ ). For the proportions of regressions made (likelihood ratio $=-12.4, p<.01$ ) and comprehension task accuracy (likelihood ratio $=-1.1, p<.05$ ), including the effects of interest did not improve fit. The effect of participants was at least marginally significant for all of the dependent variables (all $Z \mathrm{~s}>1.5, p \mathrm{~s}<.07$ ), except for comprehension accuracy and regression errors of the first regressive fixation; for simplicity, all dependent variables were analyzed with mixed models (Table 2).

Comprehension task accuracy was high $(M=.94, S D=.24)$ and was not affected by WM load, $F(1,294)=0.10, p=.75$, or by its interaction with target position, $F(1,294)=0.36, p=.55$. These null results are predicted by the rereading hypothesis; if participants were using deictic pointers to answer the comprehension questions, they should have found this more difficult under high visuospatial WM load and made more errors.

The proportion of regressions $(M=.25, S D=.43)$ was unaffected by target position or WM load (all $F_{\mathrm{s}}<0.4$, $p \mathrm{~s}>.50$ ). The facts that regressions were much less common in Experiment 2 and that their probability was not affected by

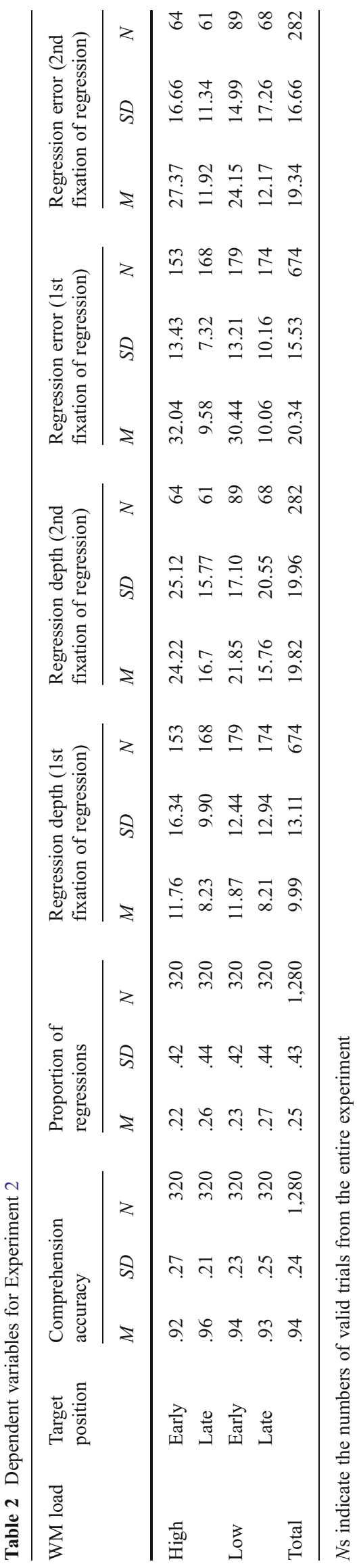


the independent variables suggest that participants were not using regressions to aid their comprehension performance, and so refutes the deictic pointer hypothesis. In general, comprehension accuracy was high but not at ceiling, yet regressions were not common. This too refutes the idea that regressions serve any function besides rereading. However, it is possible that participants would have had more need to use deictic pointers - and that WM load effects would have been detected - had the comprehension task been substantially more difficult.

Regression depth was unaffected by target position, $F(1,151)=0.03, p=.86$. This implies that participants were not aiming their regressions toward the target words. The regressions recorded in this experiment may have been artifacts of habit or reflexive returns of the gaze to the center of the screen. If these regressions did facilitate answering the comprehension question, they did not do so by allowing fixation of the target word. Either way, these results do not support a deictic pointer account of regressions in normal reading. Regression depth was also not affected by WM load, nor by the Load $\times$ Target Position interaction (both $\left.F_{\mathrm{s}}<1.6, p \mathrm{~s}>.2\right)$. This suggests that participants were not forgetting that the target word could not be reread, as this would have happened more frequently under high WM load. The second regression's depth was also unaffected by the independent variables (all $F_{\mathrm{S}}<2.2, p \mathrm{~s}>.14$ ).

The regression error of the first fixation was affected by target position, so that regressions were less accurate for early $(M=31.18, S D=13.32)$ than for late $(M=9.82, S D=$ 8.87 ) targets, $F(1,157)=7.57, p<.01$. Given that regressions were not aimed toward target words (see above), this effect may simply reflect the fact that early target words were farther from the center of the screen $(M=34$ letter spaces) than were late targets $(M=5$ letter spaces), and so were more likely to register a large regression error if participants fixated a random location on the screen. There were no other effects on this dependent variable $\left(F_{\mathrm{S}}<0.7\right.$, $p s>$.4).

The regression error of the second regression fixation was affected by WM load, so that fixations were less accurate under high load $(M=19.83, S D=16.23)$ than under low load $(M=18.96, S D=17.04), F(1,83.5)=4.39, p<$ .05 . This effect is difficult to interpret, given the small effect size $(d=0.21)$ relative to the substantial average regression error. It is possible that, if participants did attempt to fixate the target word in a minority of trials, a high visuospatial WM load made it more difficult to retain that target word's position. There were no other effects on this dependent variable $\left(F_{\mathrm{S}}<2.8, p \mathrm{~s}>.1\right)$.

Relationships between dependent variables Participants were again less accurate when they made a regression $(n=314 ; M=.90, S D=.30)$ than when they did not $(n=966 ; M=.95, S D=.22), t(1278)=2.69, p<.01, d=$ 0.21 ( $t$ is corrected for unequal variances), suggesting that participants regressed when they were unsure of the answer. However, these regressions did not assist recall of the statement sentence: There was no correlation between regression error and comprehension accuracy for either fixation of the regression $(|r| \mathrm{s}<.03, p \mathrm{~s}>.60)$.

This experiment utilized an artificial reading situation in which only visuospatial information, not word information, was available to participants if they made a regression. Participants were then encouraged to make a regression, by their having to answer a specific question about the statement. Even in this situation, in which deictic pointers would be especially useful, participants did not appear to use them. Although deictic pointers can apparently be used to aid retrieval of other types of information (see the introduction), this experiment provided no evidence that this is the function of regressions in normal reading (Ferreira et al., 2008). It did provide some support for the argument that the large number of regressions in Experiment 1's illegible condition may have partially reflected recenterings of the gaze (although note that regressions were deeper and more than three times more likely in Exp. 1's illegible condition than in Exp. 2, leaving the possibility that participants used deictic pointers in Exp. 1 but not in Exp. 2).

The possibility remains that the "reading" situation in Experiment 2 was too artificial to capture normal reading processes. Note that participants performed better on the comprehension task here than they did in Experiment 1's illegible condition, which employed a more naturalistic reading task, suggesting that they approached the two "reading" situations differently. Regressions during normal reading may allow for both rereading and the use of deictic pointers. Experiment 3 tested the rereading hypothesis in a more naturalistic reading situation.

\section{Experiment 3}

Experiment 3 was another attempt to thoroughly test the rereading and deictic pointer hypotheses. We assumed that readers are most likely to make a regression for the purpose of rereading if they are unsure about the word to which they are regressing. For example, they may forget the word and need to reread it to correctly understand the sentence. Participants should therefore not notice if the word that they regress to is different from the word that they previously read. In Experiment 3, participants read statement sentences similar to those in Experiment 1. In another variation on the gaze-contingent boundary paradigm (Rayner, 1975), we monitored their eye movements and, if they made a regression, we changed a word. If the rereading hypothesis is correct, participants should usually be unaware of this 
change. We measured this awareness in two ways: Firstly, we asked participants, after the experiment, whether they had seen any changes. Secondly, we measured whether they understood the original or the changed meaning of the sentence, by presenting both meanings as response alternatives in a comprehension test, after the statement sentence had been removed from the screen.

Note that the regressions measured here were withinsentence regressions, shorter than those studied in Experiments 1 and 2; these may not function in the same way. However, these regressions are naturally occurring, rather than being induced by a comprehension question, so in Experiment 3 we were able to assess the function of regressions in a more realistic situation than before.

\section{Method}

Participants A group of 19 students (11 female, 8 male) at the University of Kent, aged 19 to $24(M=21.63, S D=$ 1.07) took part in the experiment, either for course credit or as a favor to the experimenter. All were native English speakers with no vision or reading problems.

Design A repeated measures quasi-experimental design was used, comparing trials in which participants regressed to the target words to trials in which they did not (see the Results and Discussion section). The dependent variables were whether the participant chose the original meaning or the changed meaning on the comprehension test, and how many critical word changes they were aware of during the whole experiment.

Apparatus and stimuli The eyetracker apparatus was the same as that described previously. The stimuli were adapted from those used before (see Appx. B). Forty sentences were presented, each with a pre- and postchange variant. The difference between these was that one target word was changed. For example, one prechange sentence was "Andy is a good driver but his cousin David is not." This sentence's postchange variant was "Andy is a good dancer but his cousin David is not." The pre- and postchange words were of equal lengths. For the comprehension test, three alternative interpretations were presented, one matching the prechange meaning of the sentence (e.g., " Andy is safer on the road"), one matching the postchange meaning (e.g., "Andy has good rhythm"), and one baseline option that matched neither variant of the sentence (e.g., "Andy is safer in the water").

Procedure Participants were told that the experiment was investigating eye movements in reading. They were not told about the changing words until the end of the experiment.

Each sentence was presented once, in a random order. The sentence was presented onscreen for $2 \mathrm{~s}$. During this time, participants' eye movements were monitored. If a regression was made, the sentence switched to its postchange variant. Regressions were detected by means of an invisible boundary; if participants fixated any point more than ten character spaces beyond the critical word, and then made any right-to-left saccade, a regression was deemed to have been made. The change was implemented within one screen refresh, was made during the saccade itself, and the saccade started some distance away from the critical word (cf. Binder, Pollatsek, \& Rayner, 1999), so participants were unable to see the change itself (Matin, 1974).

After $2 \mathrm{~s}$, the sentence was replaced with the comprehension test. The three alternative interpretations (see above) were presented together in a random order, numbered from 1 to 3. Participants pressed the appropriate key on the keyboard to select their answer. They were instructed to take their time and to try to get every answer correct. Note that the statement sentence and the comprehension test were never visible at the same time, and therefore that participants could not reread the statement once they knew the comprehension questions.

After the experiment, participants were probed for suspicion about the word changes, and the number of changes that they detected was recorded.

\section{Results and discussion}

Since we were more interested in participant-level variables than before, we switched to a more conventional analytic strategy, treating participants as cases. The specific hypotheses were tested with pairwise comparisons, comparing trials on which participants regressed to the target word with trials on which they did not. Participants made regressions on $M=37.37$ out of the 40 trials and fixated the critical word during a regression on $M=5.74$ trials. Due to a clerical error, specific fixation data were only available for ten participants: These indicated that participants fixated the target word for $M=366.86 \mathrm{~ms}(S D=256.65)$ during their first reading of the sentence (i.e., before any regressions were made) and skipped the target word on $34.28 \%$ of trials. Overall, the mean fixation while reading the statement sentence was $243.06 \mathrm{~ms}(S D=162.51)$, and the mean saccade length was 11.52 letter spaces $(S D=9.44)$. The mean regression length was $10.31(S D=9.46)$ letter spaces.

Participants were more likely to select the original meaning of the sentence when they did not make a regression or did regress but did not fixate the target word (mean probability $=.70, S D=.106)$, than when they did regress and fixate the target word $(M=.26, S D=.251), t(18)=8.66, d=$ $1.99, p<.001$. Similarly, they were less likely to select the changed meaning when they did not regress to the target $(M=.20, S D=.094)$ than when they $\operatorname{did}(M=.68, S D=$ $.275), t(18)=8.16, d=1.87, p<.001$. In other words, 
fixating the changed target word strongly affected participants' interpretation of the sentence, as predicted from the rereading hypothesis.

All but two of the participants noticed the target change at least once $(M=22.68$ changes reported, $S D=30.79)$; however, participants' estimates of the number of words that changed during the experiment were not related to the number of changes that had occurred $(M=37.24, S D=$ 1.79), $r\left(19^{1}\right)=-.02, p=.95$, nor to the number of changed words that they fixated $(M=5.71, S D=2.49), r(19)=.22$, $p=.36$. Although these are null results, they do imply that participants were unaware of the changes most of the time. Together with the significant results above, these findings strongly support the rereading hypothesis.

\section{General discussion}

In three experiments, we examined whether readers make regressions to reread words or to access deictic pointers and cue their memory for what they have previously read. The results showed that (a) when previously read sentences are made illegible, which prevents rereading but retains deictic pointers, readers make fewer regressions, make less accurate regressions, and make more comprehension errors; (b) when sentence information is never presented visually but is instead accompanied by nonlinguistic deictic pointers, readers do not regress; and (c) when readers regress during normal reading, they are more influenced by what they read the second time than by what they read the first time.

These findings strongly suggest that readers make regressions to reread, rather than to cue their memory for those words. In Experiments 1 and 2, we used quite artificial reading tasks that rather encouraged regressions to be made, so their results may not reflect normal reading. However, these tasks were designed to be more likely to detect the use of deictic pointers, and yet they failed to do so. The literature already contains data on why regressions occur and what they achieve functionally: They seem to help the reader clarify ambiguities (e.g., Hyönä, 1995). The present findings elucidate how regressions achieve this function. Existing models that incorporate regressions, such as the E-Z Reader model (Pollatsek, Reichle, \& Rayner, 2006; Reichle, Warren, \& McConnell, 2009), accurately predict when regressions are likely to occur (Inhoff et al., 2009) but do not specify whether rereading is the motive, or using deictic pointers. The present experiments clarify this point.

The rereading and deictic pointer hypotheses are not mutually exclusive: Regressions may serve both purposes in normal reading. Several results in the present experiments may support this conclusion: firstly, the relatively high

\footnotetext{
${ }^{1}$ Estimates of word-change frequency were lost for two participants.
}

number of regressions in Experiment 1's illegible condition, and the fact that some of these regressions were targeted; secondly, some regressions were made in Experiment 2, despite the fact that the statement sentence was never available in this experiment (although these regressions were not aimed toward the target words). We have offered alternative accounts for these results, but these require empirical verification.

Given that eye movements seem to cue memory in other tasks (Laeng \& Teodorescu, 2002; Postle et al., 2006) and that eye movements are generally affected by the contents of visuospatial WM (Hollingworth \& Luck, 2009; Hollingworth, Richard, \& Luck, 2008), if deictic pointers are not typically used in reading, the pertinent question is why. Logically, it seems that reading - with its high demands upon WM and the stable positions of the words on the page - would be an ideal task on which to utilize deictic pointers, but the present results suggest that the average reader is reluctant to do so. There could be at least three explanations for this.

Firstly, it may be easier to reread than to use deictic pointers when WM load is high. Comprehending a long, complex sentence - the kind of sentence on which readers are likely to regress - loads WM. Droll and Hayhoe (2007) measured eye movements during a sorting task and found that when WM load was high, participants tended to switch from holding the positions of bricks in WM to repeatedly seeking them with eye movements. Irwin and Zelinsky (2002) found that their participants could remember the locations of only three to five objects in WM; reading a sentence typically requires many more fixations than this, so perhaps it is not surprising that readers prefer to reread information, rather than using a memory-based strategy, for ambiguity resolution.

Secondly, it may be that readers cannot use deictic pointers because fixating the previously fixated word overwrites the word information held in memory. ${ }^{2}$ This would make it impossible to use deictic pointers, even if readers wanted to. We know that processing fixated words can be all but unavoidable in some situations (MacLeod, 1991). Indeed, eye movements to blank space are used strategically to avoid automatically processing information: When answering questions, participants often avoid their questioner's gaze, especially when the questions are difficult (Glenberg, Schroeder, \& Robertson, 1998). This apparently prevents cognitive overload that might result from fixating the questioner's face and searching for the answer at the same time (Doherty-Sneddon \& Phelps, 2005). When reading, any regression will fixate text, and it may be very difficult for the participant to avoid rereading the fixated word.

The third, and possibly most likely, explanation is that in normal reading, the word to which the reader regresses

\footnotetext{
${ }^{2}$ We thank Françoise Vitu for alerting us to this possibility.
} 
always remains available; readers need not learn to use deictic pointers, since this gives little advantage over active rereading. Perhaps future generations of readers, with more experience of reading scrollable text on small screens, may be more inclined to use deictic pointers, as in this situation rereading is often impossible, yet the memory for where a word previously appeared would be unaffected by scrolling. Future research must elucidate the tasks for which deictic pointers could aid performance, and under what circumstances they could facilitate reading.

The present results leave us more certain about the function of longer-range regressions. However, note that, as demonstrated by Vitu and McConkie (2000), the majority of regres- sions fixate the word immediately to the left of the preregression fixation; about a quarter of regressions fixate an earlier portion of the same word (Rayner \& Pollatsek, 1989). The motivation for such short-range regressions may differ from that of the longer-range regressions studied here, perhaps by relying more heavily on deictic pointers; alternatively, immediate perceptual or semantic processes may be the dominant factor. Future research must clarify such differences.

Author note U.W.W. is now at the Department of Psychology, University of Witten/Herdecke, Germany. This work was supported by British Academy Grant No. SG-48088 to U.W.W. We are grateful to Jumana Ahmad for assistance with the data collection. We are also grateful to Dirk P. Janssen for his comments on an earlier draft of this article.

\section{Appendix A}

Table 3 Stimuli used in Experiments 1 and 2

\begin{tabular}{|c|c|c|}
\hline Statement sentence & Question sentence (early target) & Question sentence (late target) \\
\hline Amanda reads fiction, and Karen likes to be with friends. & Who has more books? & Who has more friends? \\
\hline Some sharks can hurt people, but dolphins are nice. & Which animal is dangerous? & Which animal is harmless? \\
\hline Andy is a good student but his cousin David is not. & Who is a good student? & Who is a poor student? \\
\hline Math is before noon, cognition is taught at night. & Which class starts earlier? & Which class starts later? \\
\hline Thai food is tastier and more aromatic than French food. & Which cuisine is tastier? & Which cuisine is blander? \\
\hline The kitchen is downstairs but the bathroom is upstairs. & Which room is downstairs? & Which room is upstairs? \\
\hline After you clean the table, please remove the waste. & What are you going to do first? & What are you going to do last? \\
\hline His Corvette is faster than my station wagon. & Which car is faster? & Which car is slower? \\
\hline Ann puts cinnamon in her cider but Barbara drinks it plain. & Whose cider is spicier? & Whose cider is natural? \\
\hline Humans are diurnal but raccoons are only out at night. & Who is diurnal? & Who is nocturnal? \\
\hline My mother came from England and my father from Hungary. & Who arrived from England? & Who arrived from Hungary? \\
\hline Couches are comfortable, but stools are not. & Which one is more relaxing? & Which one is less relaxing? \\
\hline Her sister is married but her brother is still single. & Who is married? & Who is single? \\
\hline Our neighbor Venus shines brighter than distant Pluto. & Which planet is brighter? & Which planet is duller? \\
\hline Ginger is a Labrador, but Navigator is a Husky. & Which dog is a Labrador? & Which dog is a Husky? \\
\hline Andrea loves roses, but she is allergic to carnations. & Thus she prefers to buy ...? & Thus she avoids to buy ... ? \\
\hline My female roommate is clean, but my male roommate is not. & Which roommate is clean? & Which roommate is messy? \\
\hline My math teacher uses charts, and my Music teacher uses diagrams. & Who uses charts? & Who uses diagrams? \\
\hline Clara wishes to stay at the party but Chrissy does not. & Who wants to stay? & Who wants to leave? \\
\hline Physicians tend to earn more money than nurses do. & Who earns more? & Who earns less? \\
\hline He wears sandals in summer and boots in winter. & What does he wear during summer? & What does he wear during winter? \\
\hline My uncle collects stamps, my aunt collects dolls. & Who needs less storage space? & Who needs more storage space? \\
\hline My doctor wears a grey coat and the nurse wears a white coat. & Who dresses darker? & Who dresses brighter? \\
\hline My college has a lot more students than my high school had. & Which place is larger? & Which place is smaller? \\
\hline My shirt is blue and my jacket is green. & Which piece of clothing is blue? & Which piece of clothing is green? \\
\hline Baseball has been more popular than soccer. & Which sport is more popular? & Which sport is less popular? \\
\hline Even small horses are heavier than big dogs. & Which animal is heavier? & Which animal is lighter? \\
\hline These glasses are for wine and those cups are for coffee. & We serve wine in ...? & We serve coffee in ...? \\
\hline My mother's $d o g$ is nice but her cat is not. & Which animal is nice? & Which animal is mean? \\
\hline My mother is younger than my father. & Who was born later? & Who was born earlier? \\
\hline
\end{tabular}


Table 3 (continued)

\begin{tabular}{|c|c|c|}
\hline Statement sentence & Question sentence (early target) & Question sentence (late target) \\
\hline He works at night and spends most of the day sleeping in bed. & When does he work? & When does he sleep? \\
\hline Gina has brown hair, my friend Kelley is a blonde. & Whose hair is brown? & Whose hair is blond? \\
\hline Poodles are faster learners than Golden Retrievers. & Which dog learns faster? & Which dog learns slower? \\
\hline Birds tend to have better vision than mammals. & Which species has keener vision? & Which species has worse vision? \\
\hline Dolphins swim much faster than sea turtles. & Which one moves faster? & Which one moves slower? \\
\hline Autumn makes Elisa sad but the sun of spring raises her spirits. & When is she sad? & When is she happy? \\
\hline His index finger was longer than his ring finger. & Which finger was longer? & Which finger was shorter? \\
\hline Tile is much more expensive than vinyl. & Which type of flooring costs more? & Which type of flooring costs less? \\
\hline Gary received a doctorate and Harry received a masters. & Who is more educated? & Who is less educated? \\
\hline I just bought this dress, but I had this jacket for years. & Which item is newer? & Which item is older? \\
\hline
\end{tabular}

Target words are italicized

\section{Appendix B}

Table 4 Stimuli used in Experiment 3

\begin{tabular}{|c|c|c|c|c|}
\hline $\begin{array}{l}\text { Statement sentence } \\
\text { (prechange) }\end{array}$ & $\begin{array}{l}\text { Statement sentence } \\
\text { (postchange) }\end{array}$ & $\begin{array}{l}\text { Question sentence } \\
\text { (prechange meaning) }\end{array}$ & $\begin{array}{l}\text { Question sentence } \\
\text { (postchange meaning) }\end{array}$ & $\begin{array}{l}\text { Question sentence } \\
\text { (neutral meaning) }\end{array}$ \\
\hline $\begin{array}{l}\text { Amanda reads fiction, } \\
\text { and Karen likes to } \\
\text { be with friends. }\end{array}$ & $\begin{array}{l}\text { Amanda reads fiction, and } \\
\text { Brian likes to be with } \\
\text { friends. }\end{array}$ & $\begin{array}{l}\text { Karen is more } \\
\text { popular than } \\
\text { Amanda. }\end{array}$ & $\begin{array}{l}\text { Brian is more } \\
\text { popular than } \\
\text { Amanda. }\end{array}$ & $\begin{array}{l}\text { Neill is more popular } \\
\text { than Amanda. }\end{array}$ \\
\hline $\begin{array}{l}\text { Some sharks can hurt people, } \\
\text { but dolphins are nice. }\end{array}$ & $\begin{array}{l}\text { Some sharks can hurt people, } \\
\text { but sealions are nice. }\end{array}$ & $\begin{array}{l}\text { Dolphins don’t } \\
\text { hurt people. }\end{array}$ & $\begin{array}{l}\text { Sealions don't } \\
\text { hurt people. }\end{array}$ & $\begin{array}{l}\text { Starfish don't } \\
\text { hurt people. }\end{array}$ \\
\hline $\begin{array}{l}\text { Andy is a good driver but } \\
\text { his cousin David is not. }\end{array}$ & $\begin{array}{l}\text { Andy is a good dancer but } \\
\text { his cousin David is not. }\end{array}$ & $\begin{array}{l}\text { Andy is safer } \\
\text { on the road. }\end{array}$ & $\begin{array}{l}\text { Andy has } \\
\text { good rhythm. }\end{array}$ & $\begin{array}{l}\text { Andy is safer } \\
\text { in the water. }\end{array}$ \\
\hline $\begin{array}{l}\text { Math is before noon, French } \\
\text { is taught at night. }\end{array}$ & $\begin{array}{l}\text { Math is before noon, } \\
\text { German is taught at night. }\end{array}$ & $\begin{array}{l}\text { Math is earlier } \\
\text { than French. }\end{array}$ & $\begin{array}{l}\text { Math is earlier } \\
\text { than German. }\end{array}$ & $\begin{array}{l}\text { Math is earlier } \\
\text { than Latin. }\end{array}$ \\
\hline $\begin{array}{c}\text { Thai food is tastier and more } \\
\text { aromatic than French food. }\end{array}$ & $\begin{array}{l}\text { Thai food is tastier and more } \\
\text { colorful than French food. }\end{array}$ & $\begin{array}{l}\text { French food doesn't } \\
\text { smell as good. }\end{array}$ & $\begin{array}{l}\text { French food doesn't } \\
\text { look as good. }\end{array}$ & $\begin{array}{l}\text { French food } \\
\text { isn't as healthy. }\end{array}$ \\
\hline $\begin{array}{l}\text { The kitchen is downstairs but } \\
\text { the bathroom is upstairs. }\end{array}$ & $\begin{array}{l}\text { The parlour is downstairs } \\
\text { but the bathroom is upstairs. }\end{array}$ & We cook downstairs. & We relax downstairs. & We shower downstairs. \\
\hline $\begin{array}{l}\text { After you clean the table, } \\
\text { please remove the waste. }\end{array}$ & $\begin{array}{l}\text { After you paint the table, } \\
\text { please remove the waste. }\end{array}$ & $\begin{array}{l}\text { You just had } \\
\text { some dinner. }\end{array}$ & $\begin{array}{l}\text { You just did } \\
\text { some DIY. }\end{array}$ & You just played a game. \\
\hline $\begin{array}{l}\text { His Corvette is older than } \\
\text { my station wagon. }\end{array}$ & $\begin{array}{l}\text { His Corvette is newer } \\
\text { than my station wagon. }\end{array}$ & $\begin{array}{l}\text { My car is the } \\
\text { newest. }\end{array}$ & My car is the oldest. & My car is the slowest. \\
\hline $\begin{array}{l}\text { Jon puts cinnamon in } \\
\text { his cider but Barbara } \\
\text { drinks it plain. }\end{array}$ & $\begin{array}{l}\text { Joe puts cinnamon in his cider } \\
\text { but Barbara drinks it plain. }\end{array}$ & $\begin{array}{l}\text { Jon likes a } \\
\text { spicier drink. }\end{array}$ & $\begin{array}{l}\text { Joe likes a } \\
\text { spicier drink. }\end{array}$ & $\begin{array}{l}\text { Bob likes a } \\
\text { spicier drink. }\end{array}$ \\
\hline $\begin{array}{l}\text { Humans are diurnal } \\
\text { but raccoons are } \\
\text { only out at night. }\end{array}$ & $\begin{array}{l}\text { Horses are diurnal but } \\
\text { raccoons are only } \\
\text { out at night. }\end{array}$ & $\begin{array}{l}\text { Humans are awake } \\
\text { during the day. }\end{array}$ & $\begin{array}{c}\text { Horses are awake } \\
\text { during the day. }\end{array}$ & $\begin{array}{l}\text { Hares are awake } \\
\text { during the day. }\end{array}$ \\
\hline $\begin{array}{l}\text { My mother came from } \\
\text { England and my } \\
\text { father from Hungary. }\end{array}$ & $\begin{array}{l}\text { My mother came from Ireland } \\
\text { and my father from } \\
\text { Hungary. }\end{array}$ & $\begin{array}{l}\text { My mother is } \\
\text { English. }\end{array}$ & My mother is Irish. & My mother is Scottish. \\
\hline $\begin{array}{l}\text { Couches are comfortable, } \\
\text { but stools are not. }\end{array}$ & $\begin{array}{l}\text { Settees are comfortable, } \\
\text { but stools are not. }\end{array}$ & $\begin{array}{l}\text { Couches are } \\
\text { more relaxing. }\end{array}$ & $\begin{array}{l}\text { Settees are } \\
\text { more relaxing. }\end{array}$ & $\begin{array}{l}\text { Sofas are more } \\
\text { relaxing. }\end{array}$ \\
\hline $\begin{array}{l}\text { Her sister is married but } \\
\text { her brother is still single. }\end{array}$ & $\begin{array}{l}\text { Her sister is engaged but } \\
\text { her brother is still single. }\end{array}$ & $\begin{array}{l}\text { Her sister has already } \\
\text { gotten married. }\end{array}$ & $\begin{array}{l}\text { Her sister will be } \\
\text { getting married. }\end{array}$ & $\begin{array}{l}\text { Her sister will be } \\
\text { having a baby. }\end{array}$ \\
\hline $\begin{array}{l}\text { Distant Pluto shines dimmer } \\
\text { than our neighbour Venus. }\end{array}$ & $\begin{array}{l}\text { Distant Pluto shines longer } \\
\text { than our neighbour Venus. }\end{array}$ & Venus is brighter. & $\begin{array}{l}\text { Venus is visible for } \\
\text { a shorter time. }\end{array}$ & Venus is dimmer. \\
\hline $\begin{array}{l}\text { Ginger is an Alsatian, but } \\
\text { Navigator is a Husky. }\end{array}$ & $\begin{array}{l}\text { Ginger is an Airedale, but } \\
\text { Navigator is a Husky. }\end{array}$ & $\begin{array}{l}\text { There is a Husky } \\
\text { and an Alsatian. }\end{array}$ & $\begin{array}{l}\text { There is a Husky } \\
\text { and an Airedale. }\end{array}$ & $\begin{array}{l}\text { There is a Husky } \\
\text { and a Dalmatian. }\end{array}$ \\
\hline $\begin{array}{l}\text { Andrea loves roses, but she } \\
\text { is allergic to carnations. }\end{array}$ & $\begin{array}{l}\text { Audrey loves roses, but she } \\
\text { is allergic to carnations. }\end{array}$ & $\begin{array}{l}\text { Andrea avoids } \\
\text { buying carnations. }\end{array}$ & $\begin{array}{l}\text { Audrey avoids } \\
\text { buying carnations. }\end{array}$ & $\begin{array}{l}\text { Alice avoids buying } \\
\text { carnations. }\end{array}$ \\
\hline
\end{tabular}


Table 4 (continued)

\begin{tabular}{|c|c|c|c|c|}
\hline $\begin{array}{l}\text { Statement sentence } \\
\text { (prechange) }\end{array}$ & $\begin{array}{l}\text { Statement sentence } \\
\text { (postchange) }\end{array}$ & $\begin{array}{l}\text { Question sentence } \\
\text { (prechange meaning) }\end{array}$ & $\begin{array}{l}\text { Question sentence } \\
\text { (postchange meaning) }\end{array}$ & $\begin{array}{l}\text { Question sentence } \\
\text { (neutral meaning) }\end{array}$ \\
\hline $\begin{array}{l}\text { My female roommate is clean, } \\
\text { but my male roommate is } \\
\text { not. }\end{array}$ & $\begin{array}{l}\text { My female roommate is } \\
\text { quiet, but my male } \\
\text { roommate is not. }\end{array}$ & $\mathrm{He}$ is messier. & $\mathrm{He}$ is louder. & $\mathrm{He}$ is friendlier. \\
\hline $\begin{array}{l}\text { My math teacher uses charts, } \\
\text { and my Music teacher } \\
\text { uses diagrams. }\end{array}$ & $\begin{array}{l}\text { My math teacher uses slides, } \\
\text { and my Music teacher } \\
\text { uses diagrams. }\end{array}$ & $\begin{array}{l}\text { I learn math } \\
\text { from charts. }\end{array}$ & I learn math from slides. & $\begin{array}{l}\text { I learn math } \\
\text { from books. }\end{array}$ \\
\hline $\begin{array}{l}\text { Clara wishes to stay at the } \\
\text { party but Chrissy does not. }\end{array}$ & $\begin{array}{l}\text { Clara wishes to stay at the } \\
\text { disco but Chrissy does not. }\end{array}$ & $\begin{array}{l}\text { Chrissy is bored } \\
\text { of the party. }\end{array}$ & $\begin{array}{l}\text { Chrissy is bored } \\
\text { of the disco. }\end{array}$ & $\begin{array}{l}\text { Chrissy is bored } \\
\text { of the game. }\end{array}$ \\
\hline $\begin{array}{l}\text { Physicians tend to earn more } \\
\text { money than nurses do. }\end{array}$ & $\begin{array}{l}\text { Scientists tend to earn more } \\
\text { money than nurses do. }\end{array}$ & $\begin{array}{l}\text { Nurses are poorer } \\
\text { than physicians. }\end{array}$ & $\begin{array}{l}\text { Nurses are poorer } \\
\text { than scientists. }\end{array}$ & $\begin{array}{l}\text { Nurses are poorer } \\
\text { than lawyers. }\end{array}$ \\
\hline $\begin{array}{l}\text { He wears sandals in summer } \\
\text { and boots in winter. }\end{array}$ & $\begin{array}{l}\text { He sells sandals in summer } \\
\text { and boots in winter. }\end{array}$ & $\begin{array}{l}\text { He wears different } \\
\text { shoes at different } \\
\text { times. }\end{array}$ & $\begin{array}{l}\text { He sells different shoes } \\
\text { at different times. }\end{array}$ & $\begin{array}{l}\text { He buys different shoes } \\
\text { at different times. }\end{array}$ \\
\hline $\begin{array}{l}\text { My uncle collects stamps, } \\
\text { my aunt collects dolls. }\end{array}$ & $\begin{array}{l}\text { My uncle collects albums, } \\
\text { my aunt collects dolls. }\end{array}$ & He has a lot of stamps. & He has a lot of albums. & He has a lot of books. \\
\hline $\begin{array}{l}\text { My doctor wears a grey coat } \\
\text { and the nurse wears a } \\
\text { white coat. }\end{array}$ & $\begin{array}{l}\text { My doctor wears a blue } \\
\text { coat and the nurse } \\
\text { wears a white coat. }\end{array}$ & The doctor wears grey. & The doctor wears blue. & The doctor wears black. \\
\hline $\begin{array}{l}\text { My college has a lot more } \\
\text { students than my high } \\
\text { school had. }\end{array}$ & $\begin{array}{l}\text { My college has a lot more } \\
\text { teachers than my } \\
\text { high school had. }\end{array}$ & $\begin{array}{l}\text { High school had } \\
\text { less students. }\end{array}$ & $\begin{array}{l}\text { High school had } \\
\text { less teachers. }\end{array}$ & $\begin{array}{l}\text { High school had } \\
\text { less facilities. }\end{array}$ \\
\hline $\begin{array}{l}\text { My shirt is blue and my } \\
\text { jacket is green. }\end{array}$ & $\begin{array}{l}\text { My scarf is blue and my } \\
\text { jacket is green. }\end{array}$ & I have a blue shirt. & I have a blue scarf. & I have a blue skirt. \\
\hline $\begin{array}{l}\text { Baseball has been more } \\
\text { popular than soccer. }\end{array}$ & $\begin{array}{l}\text { Baseball has been } \\
\text { less popular than soccer. }\end{array}$ & $\begin{array}{l}\text { More people } \\
\text { play baseball. }\end{array}$ & More people play soccer. & $\begin{array}{l}\text { More people play } \\
\text { tennis. }\end{array}$ \\
\hline $\begin{array}{l}\text { Even small horses are } \\
\text { heavier than big dogs. }\end{array}$ & $\begin{array}{l}\text { Some small horses are } \\
\text { heavier than big dogs. }\end{array}$ & All horses are heavier. & $\begin{array}{l}\text { Not all horses are } \\
\text { heavier. }\end{array}$ & Not all horses are faster. \\
\hline $\begin{array}{l}\text { These glasses are for wine and } \\
\text { those cups are for coffee. }\end{array}$ & $\begin{array}{l}\text { These glasses are for beer } \\
\text { and those cups are } \\
\text { for coffee. }\end{array}$ & We are drinking wine. & We are drinking beer. & We are drinking gin. \\
\hline $\begin{array}{l}\text { My mother's dog is nice } \\
\text { but her cat is not. }\end{array}$ & $\begin{array}{l}\text { My sister's dog is nice } \\
\text { but her cat is not. }\end{array}$ & $\begin{array}{l}\text { My mother's } \\
\text { cat is mean. }\end{array}$ & My sister's cat is mean. & $\begin{array}{l}\text { My mother's } \\
\text { dog is mean. }\end{array}$ \\
\hline $\begin{array}{l}\text { My mother is younger } \\
\text { than my father. }\end{array}$ & $\begin{array}{l}\text { My mother is slimmer } \\
\text { than my father. }\end{array}$ & My father is older. & My father is fatter. & My father is taller. \\
\hline $\begin{array}{l}\text { He works at night and } \\
\text { spends most of the day } \\
\text { sleeping in bed. }\end{array}$ & $\begin{array}{l}\text { He works at night and } \\
\text { spends some of the day } \\
\text { sleeping in bed. }\end{array}$ & $\begin{array}{l}\text { He sleeps most } \\
\text { of the day. }\end{array}$ & $\begin{array}{l}\text { He sleeps some } \\
\text { of the day. }\end{array}$ & $\begin{array}{l}\text { He sleeps all } \\
\text { of the day. }\end{array}$ \\
\hline $\begin{array}{l}\text { Gina has brown hair, my } \\
\text { friend Kelley is a blonde. }\end{array}$ & $\begin{array}{l}\text { Gina has brown hair, my } \\
\text { cousin Kelley is a blonde. }\end{array}$ & Kelley is my friend. & Kelley is my cousin. & Kelley is my niece. \\
\hline $\begin{array}{l}\text { Poodles are faster learners } \\
\text { than Golden Retrievers. }\end{array}$ & $\begin{array}{l}\text { Collies are faster learners } \\
\text { than Golden Retrievers. }\end{array}$ & Poodles are clever. & Collies are clever. & Bulldogs are clever. \\
\hline $\begin{array}{l}\text { Birds tend to have better } \\
\text { vision than mammals. }\end{array}$ & $\begin{array}{l}\text { Birds tend to need better } \\
\text { vision than mammals. }\end{array}$ & $\begin{array}{l}\text { Good sight is more } \\
\text { common in birds. }\end{array}$ & $\begin{array}{l}\text { Good sight is more } \\
\text { important in birds. }\end{array}$ & $\begin{array}{l}\text { Good sight is } \\
\text { more rare in birds. }\end{array}$ \\
\hline $\begin{array}{l}\text { Dolphins swim much } \\
\text { faster than sea turtles. }\end{array}$ & $\begin{array}{l}\text { Dolphins swim much } \\
\text { deeper than sea turtles. }\end{array}$ & Turtles swim slower. & Turtles swim shallower. & Turtles swim harder. \\
\hline $\begin{array}{l}\text { Autumn makes Elisa sad } \\
\text { but the sun of spring } \\
\text { raises her spirits. }\end{array}$ & $\begin{array}{l}\text { Winter makes Elisa sad } \\
\text { but the sun of spring } \\
\text { raises her spirits. }\end{array}$ & $\begin{array}{l}\text { She's happier in } \\
\text { spring than in } \\
\text { autumn. }\end{array}$ & $\begin{array}{l}\text { She's happier in } \\
\text { spring than in winter. }\end{array}$ & $\begin{array}{l}\text { She's happier in } \\
\text { summer than in } \\
\text { winter. }\end{array}$ \\
\hline $\begin{array}{l}\text { His index finger was } \\
\text { shorter than his ring finger. }\end{array}$ & $\begin{array}{l}\text { His index finger was thicker } \\
\text { than his ring finger. }\end{array}$ & $\begin{array}{l}\text { His ring finger } \\
\text { is longer. }\end{array}$ & $\begin{array}{l}\text { His ring finger } \\
\text { is thinner. }\end{array}$ & $\begin{array}{l}\text { His ring finger is } \\
\text { shorter. }\end{array}$ \\
\hline $\begin{array}{l}\text { Tile is much more } \\
\text { expensive than vinyl. }\end{array}$ & $\begin{array}{l}\text { Tile is much less } \\
\text { expensive than vinyl. }\end{array}$ & Tile is pricier. & Tile is cheaper. & Tile is tougher. \\
\hline $\begin{array}{l}\text { Gary received a doctorate and } \\
\text { Harry received a masters. }\end{array}$ & $\begin{array}{l}\text { John received a doctorate and } \\
\text { Harry received a masters. }\end{array}$ & $\begin{array}{l}\text { Gary is more } \\
\text { educated. }\end{array}$ & John is more educated. & Dave is more educated. \\
\hline $\begin{array}{l}\text { I just bought this dress, but } \\
\text { I had this jacket for years. }\end{array}$ & $\begin{array}{l}\text { I just rented this dress, but } \\
\text { I had this jacket for years. }\end{array}$ & The dress is new. & The dress is borrowed. & The dress is old. \\
\hline
\end{tabular}




\section{References}

Altmann, G. T. M. (2004). Language-mediated eye movements in the absence of a visual world: The "blank screen paradigm. Cognition, 93, B79-B87. doi:10.1016/j.cognition.2004.02.005

Altmann, G. T. M., \& Kamide, Y. (2009). Discourse-mediation of the mapping between language and the visual world: Eye movements and mental representation. Cognition, 11, 55-71. doi:10.1016/ j.cognition.2008.12.005

Ballard, D. H., Hayhoe, M. M., Pook, P. K., \& Rao, R. P. N. (1997). Deictic codes for the embodiment of cognition. Behavioral and Brain Sciences, 20, 723-767.

Binder, K. S., Pollatsek, A., \& Rayner, K. (1999). Extraction of information to the left of the fixated word in reading. Journal of Experimental Psychology. Human Perception and Performance, 25, 1162-1172. doi:10.1037/0096-1523.25.4.1162

Blanchard, H. E., \& Iran-Nejad, A. (1987). Comprehension processes and eye movement patterns in the reading of surprise-ending stories. Discourse Processes, 10, 127-138.

Borst, G., \& Kosslyn, S. M. (2008). Visual mental imagery and visual perception: Structural equivalence revealed by scanning processes. Memory \& Cognition, 36, 849-862. doi:10.3758/MC.36.4.849

Brandt, S. A., \& Stark, L. W. (1997). Spontaneous eye movements during visual imagery reflect the content of the visual scene. Journal of Cognitive Neuroscience, 9, 27-38.

Calvo, M. G., \& Eysenck, M. W. (1996). Phonological working memory and reading in test anxiety. Memory, 4, 289-305. doi:10.1080/ 096582196388960

Doherty-Sneddon, G., \& Phelps, F. G. (2005). Gaze aversion: A response to cognitive or social difficulty? Memory \& Cognition, 33, 727-733. doi:10.3758/BF03195338

Droll, J. A., \& Hayhoe, M. M. (2007). Trade-offs between gaze and working memory use. Journal of Experimental Psychology. Human Perception and Performance, 33, 1352-1365. doi:10.1037/ 0096-1523.33.6.1352

Ferreira, F., Apel, J., \& Henderson, J. M. (2008). Taking a new look at looking at nothing. Trends in Cognitive Sciences, 12, 405-410. doi:10.1016/j.tics.2008.07.007

Frazier, L., \& Rayner, K. (1982). Making and correcting errors during sentence comprehension: Eye movements in the analysis of structurally ambiguous sentences. Cognitive Psychology, 14, 178-210. doi:10.1016/0010-0285(82)90008-1

Glenberg, A. M., Schroeder, J. L., \& Robertson, D. A. (1998). Averting the gaze disengages the environment and facilitates remembering. Memory \& Cognition, 26, 651-658. doi:10.3758/BF03211385

Hale, S., Myerson, J., Rhee, S. H., Weiss, C. S., \& Abrams, R. A. (1996). Selective interference with the maintenance of location information in working memory. Neuropsychology, 10, 228-240.

Hebb, D. O. (1968). Concerning imagery. Psychological Review, 75, 466-477. doi:10.1037/h0026771

Hollingworth, A., \& Luck, S. J. (2009). The role of visual working memory in the control of gaze during visual search. Attention, Perception, \& Psychophysics, 71, 936-949. doi:10.3758/ APP.71.4.936

Hollingworth, A., Richard, A. M., \& Luck, S. J. (2008). Understanding the function of visual short-term memory: Transsaccadic memory, object correspondence, and gaze correction. Journal of Experimental Psychology. General, 137, 163-181. doi:10.1037/00963445.137.1.163

Hyönä, J. (1995). An eye movement analysis of topic-shift effect during repeated reading. Journal of Experimental Psychology: Learning, Memory, and Cognition, 21, 1365-1373. doi:10.1037/ 0278-7393.21.5.1365

Inhoff, A. W., Greenberg, S. N., Solomon, M., \& Wang, C.-A. (2009). Word integration and regression programming during reading: A test of the E-Z Reader 10 model. Journal of Experimental Psychology. Human Perception and Performance, 35, 1571-1584. doi:10.1037/a0014250

Inhoff, A. W., \& Weger, U. W. (2005). Memory for word location during reading: Eye movements to previously read words are spatially selective but not precise. Memory \& Cognition, 33, 447-461. doi:10.3758/BF03193062

Irwin, D. E., \& Zelinsky, G. J. (2002). Eye movements and scene perception: Memory for things observed. Perception \& Psychophysics, 64, 882-895.

Janssen, D. P. (2012). Twice random, once mixed: Applying mixed models to simultaneously analyze random effects of language and participants. Behavior Research Methods, 44, 232-247. doi:10.3758/s13428-011-0145-1

Kennedy, A. (1992). The spatial coding hypothesis. In K. Rayner (Ed.), Eye movements and visual cognition: Scene perception and reading (pp. 379-396). New York, NY: Springer.

Kennedy, A., \& Murray, W. S. (1987). Spatial coordinates and reading: Comments on Monk (1985). Quarterly Journal of Experimental Psychology, 39A, 649-656.

Kolers, P. A. (1968). Foreword. In E. B. Huey (Ed.), The psychology and pedagogy of reading (pp. xviii-xix). Cambridge, MA: MIT Press.

Laeng, B., \& Teodorescu, D.-S. (2002). Eye scanpaths during visual imagery reenact those of perception of the same visual scene. Cognitive Science, 26, 207-231.

Lawrence, B. M., Myerson, J., \& Abrams, R. A. (2004). Interference with spatial working memory: An eye movement is more than a shift of attention. Psychonomic Bulletin \& Review, 11, 488-494. doi:10.3758/BF03196600

Lawrence, B. M., Myerson, J., Oonk, H. M., \& Abrams, R. A. (2001). The effects of eye and limb movements on working memory. Memory, 9, 433-444. doi:10.1080/09658210143000047

MacLeod, C. M. (1991). Half a century of research on the Stroop effect: An integrative review. Psychological Bulletin, 109, 163203. doi:10.1037/0033-2909.109.2.163

Mast, F. W., \& Kosslyn, S. M. (2002). Eye movements during visual mental imagery. Trends in Cognitive Sciences, 6, 271-272. doi:10.1016/S1364-6613(02)01931-9

Matin, E. (1974). Saccadic suppression: A review and an analysis. Psychological Bulletin, 81, 899-917. doi:10.1037/h0037368

McConkie, G. W., Kerr, P. W., Reddix, M. D., \& Zola, D. (1988). Eye movement control during reading: I. The location of initial eye fixation on words. Vision Research, 28, 1107-1118.

O'Regan, J. K. (1992). Solving the "real" mysteries of visual perception: The world as an outside memory. Canadian Journal of Psychology, 46, 461-488. doi:10.1037/h0084327

Pollatsek, A., Reichle, E. D., \& Rayner, K. (2006). Tests of the E-Z Reader model: Exploring the interface between cognition and eye-movement control. Cognitive Psychology, 52, 1-56. doi:10.1016/j.cogpsych.2005.06.001

Postle, B. R., Idzikowski, C., Della Salla, S., Logie, R. H., \& Baddeley, A. D. (2006). The selective disruption of spatial working memory by eye movements. Quarterly Journal of Experimental Psychology, 59, 100-120. doi:10.1080/17470210500151410

Rayner, K. (1975). The perceptual span and peripheral cues in reading. Cognitive Psychology, 7, 65-81. doi:10.1016/0010-0285 (75) $90005-5$

Rayner, K. (1998). Eye movements in reading and information processing: 20 years of research. Psychological Bulletin, 124, 372422. doi:10.1037/0033-2909.124.3.372

Rayner, K. (2009). Eye movements and attention in reading, scene perception, and visual search. Quarterly Journal of Experimental Psychology, 62, 1457-1506. doi:10.1080/17470210902816461

Rayner, K., \& Pollatsek, A. (1989). The psychology of reading. Englewood Cliffs, NJ: Prentice Hall. 
Reichle, E. D., Warren, T., \& McConnell, K. (2009). Using E-Z Reader to model the effects of higher-level language processing on eye movements during reading. Psychonomic Bulletin \& Review, 16, 1-21. doi:10.3758/PBR.16.1.1

Richardson, D. C., \& Spivey, M. J. (2000). Representation, space and Hollywood Squares: Looking at things that aren't there anymore. Cognition, 76, 269-295. doi:10.1016/S0010-0277 (00)00084-6

Richter, T. (2006). What is wrong with ANOVA and multiple regression? Analyzing sentence reading times with hierarchical linear models. Discourse Processes, 41, 221-250. doi:10.1207/ s15326950dp4103_1

Spivey, M. J., \& Geng, J. J. (2001). Oculomotor mechanisms activated by imagery and memory: Eye movements to absent objects. Psychological Research, 65, 235-241.
Spivey, M. J., Richardson, D. C., \& Fitneva, S. A. (2004). Thinking outside the brain: Spatial indices to visual and linguistic information. In J. M. Henderson \& F. Ferreira (Eds.), The interface of language, vision, and action: Eye movements and the visual world (pp. 161-189). New York, NY: Psychology Press.

Theeuwes, J., Belopolsky, A., \& Olivers, C. N. L. (2009). Interactions between working memory, attention and eye movements. Acta Psychologica, 132, 106-114. doi:10.1016/j.actpsy.2009.01.005

Vitu, F. M. (2005). Visual extraction processes and regressive saccades in reading. In G. Underwood (Ed.), Cognitive processes in eye guidance (pp. 1-32). Oxford, U.K.: Oxford University Press.

Vitu, F. M., \& McConkie, G. W. (2000). Regressive saccades and word perception in adult perception. In A. Kennedy, R. Radach, \& J. Pynte (Eds.), Reading as a perceptual process (pp. 89-118). Amsterdam, The Netherlands: Elsevier. 